\title{
Optimasi Kondisi Pemisahan Glibenklamid Kombinasi Metformin dengan KCKT-SPE MIP Akrilamid
}

\author{
Aliya N. Hasanah, Pramuja A. Martha, Nyi M. Saptarini, Anisa D. Aryanti \\ Fakultas Farmasi Universitas Padjadjaran, Sumedang, Jawa Barat, Indonesia
}

\begin{abstract}
Abstrak
Telah dilakukan dan divalidasi metode analisis glibenklamid dalam plasma menggunakan kromatografi cair kinerja tinggi fase terbalik dengan pretreatment menggunakan SPE C-18 dan SPE-MIP monomer akrilamid. $1 \mathrm{~mL}$ metanol dan $1 \mathrm{~mL}$ akuabides digunakan sebagai conditioning agent, $1 \mathrm{~mL}$ metanol $5 \%$ dalam akuabides digunakan sebagai washing agent, dan $1 \mathrm{~mL}$ asetonitril digunakan sebagai eluting agent. Hasil ekstraksi sampel plasma darah dianalisis menggunakan kolom $\mathrm{C}_{18}$ (Shimadzu) $150 \times 4,6$ $\mathrm{mm}$, ukuran partkel $5 \mu \mathrm{m}$, fase gerak 55:45 $\mathrm{v} / \mathrm{v}$ asetonitril dan triflouro acid $0,1 \%$ dengan kecepatan alir $1 \mathrm{~mL} /$ menit, deteksi dilakukan pada $227 \mathrm{~nm}$ dengan standar internal gliklazid. Metode analisis divalidasi berdasarkan parameter linieritas, presisi, akurasi, selektivitas/spesifisitas, Limit of Detection (LOD), Limit of Quantification (LOQ) dan kesesuaian sistem. Dapat disimpulkan bahwa metode analisis yang digunakan memiliki validitas sesuai dengan yang dipersyaratkan dan SPE-MIP monomer akrilamid memberikan hasil ekstrasi yang lebih optimal dibandingkan dengan SPE C-18.
\end{abstract}

Kata kunci: Akrilamid, analisis, C-18, glibenklamid, KCKT, SPE-MIP

\section{Optimisation of Glibenclamide Combination with Metformine Separation Conditions by means of HPLC-UV MIP Acrylamide}

\begin{abstract}
Two analyticals methods for glibenclamide based on reverse phase high-performace liquid chromatography pretreatmented by SPE C-18 and SPE-MIP acrylamide monomer was developed and validated. Samples were extracted using $1 \mathrm{~mL}$ methanol and $1 \mathrm{~mL}$ of distilled water as a conditioning agent, $1 \mathrm{~mL}$ of $5 \%$ methanol in distilled water as a washing agent, and $1 \mathrm{~mL}$ acetonitrile as eluting agent. Extraction results were analyzed using a $\mathrm{C}_{18}$ column (Shimadzu) $150 \times 4.6 \mathrm{~mm}$, with particle size $5 \mu \mathrm{m}$, Mobile phase 55:45 v/v acetonitrile and triflouro acid $0.1 \%$ with a flow rate of $1 \mathrm{~mL} / \mathrm{min}$, detection was done at $227 \mathrm{~nm}$ with gliclazide as internal standard. Validated analytical methods based on these parameters: linearity, precision, accuracy, selectivity/specificity, LOD, LOQ and system suitability. It can be concluded that the method of analysis is validated and SPE-MIP acrylamide monomer extraction yield is more optimal than SPE C-18.
\end{abstract}

Keywords: Acrylamide, analysis, C-18, glibenclamide, HPLC, SPE-MIP 


\section{Pendahuluan}

Diabetes mellitus (DM) merupakan sekelompok gangguan heterogen yang ditandai oleh kelainan dalam metabolisme karbohidrat, protein dan lemak. ${ }^{1}$ DM merupakan kelainan metabolik yang paling umum terjadi, dengan perkiraan prevalensi seluruh dunia antara 1-5\%. Secara global, jumlah penderita DM terus meningkat. ${ }^{2}$ International Diabetes Federation (IDF) (2012) menyatakan bahwa di tahun 2011 sekitar 366 juta orang menderita DM dan diramalkan jumlah penderita pada tahun 2030 akan mencapai 552 juta orang. ${ }^{3}$ Pada dekade terakhir telah diketahui bahwa prevalensi DM tipe 2 meningkat secara cepat. Telah diprediksi bahwa sedikitnya 350 juta orang di seluruh dunia akan menderita DM tipe 2 pada tahun $2030{ }^{2}$

Hasil penelitian di beberapa apotek di Surabaya terkait dengan peresepan obat antidiabetik menunjukkan bahwa golongan antidiabetik oral yang sering digunakan adalah sulfonilurea sebesar 52,7\% dimana 29,9\%-nya adalah glibenklamid. Urutan kedua adalah golongan biguanid $(32,4 \%)$ yang $29,6 \%$-nya merupakan peresepan metformin. ${ }^{4}$

Pada saat analisis glibenklamid dalam darah dengan KCKT dilakukan pretreatment sampel menggunakan Solid Phase Extraction (SPE) konvensional. SPE jenis ini memiliki kekurangan dari segi selektivitas absorbsinya. ${ }^{5}$ Karena kekurangan dari SPE konvensional tersebut, kolom SPE telah berkembang pada SPEMIP (Molecularly Imprinted Polymer). Karena penggunaan glibenklamid tinggi diantara golongan sulfonilurea yang lain dan seringnya obat ini dikombinasikan maka dibuat SPE-MIP glibenklamid dengan berbagai monomer fungsional salah satunya adalah akrilamid.

SPE-MIP yang telah dibuat perlu dioptimasi kondisinya sehingga akan menghasilkan metode analisis yang sesuai peruntukannya. Penelitian ini dilakukan untuk memperoleh kondisi optimum ekstraksi glibenklamid dari sampel plasma darah menggunakan kolom SPE-MIP monomer akrilamid yang telah dibuat sebelumnya untuk kemudian dilakukan analisis dengan KCKT. Penelitian dilakukan dengan tahapan optimasi kondisi ekstraksi, uji kesesuaian sistem KCKT dan validasi metode analisis. Hasil pengujian akan dibandingkan dengan pengujian menggunakan kolom SPE konvensional untuk mengetahui performance SPE-MIP monomer akrilamid yang telah dibuat.

\section{Metode}

Alat yang digunakan dalam penelitian ini adalah alat gelas yang umum digunakan di laboratorium analitik, yaitu mikropipet $100-1000 \mu \mathrm{L}$, mikropipet $20-200 \mu \mathrm{L}$, timbangan analitis (Sartorius), syringe, pHmeter (Mettler Toledo), ultrasonic bath (Ney 1510 dan Branson), kolom KCKT dengan panjang $150 \mathrm{~mm}$, diameter $4,6 \mathrm{~mm}$, ukuran partikel $5 \mu \mathrm{m}$,SPE C-18 dan kolom SPE-MIP monomer akrilamid, penyaring vakum, saringan berpori $0,4-0,45 \mu \mathrm{m}$ (Sartorius), KCKT (Dionex C-18) dengan detektor Ultraviolet Manual Sample Injecto Valve for (Dionex Ultimate 3000) serta spektrofotometer ultraviolet-sinar tampak (Analytic Jena, Specord 200).

Bahan-bahan yang digunakan di dalam penelitian ini adalah glibenklamid (PT. Hexapham), metformin (PT. Kalbe Farma), gliklazid (PT. Dexa), plasma manusia (PMI Bandung), asetonitril (J.T.Baker), triflouro acid (merck), metanol (merck), dan akuabides (IFHA).

Penelitian dimulai dengan melakukan penyiapan bahan dan membuat fase gerak, optimasi kondisi KCKT dan uji kesesuaian sistem, validasi metode analisis, serta pengolahan data.

Penyiapan bahan dan pembuatan fase gerak terdiri dari pembuatan larutan baku glibenklamid, larutan baku metformin, larutan baku gliklazid, pembuatan larutan trifluoro acid (TFA), dan pembuatan dapar fosfat. 
Larutan baku glibenklamid, metformin dan gliklazid dibuat dengan konsentrasi $500 \mu \mathrm{g} / \mathrm{m}$ dalam metanol. Larutan TFA $0,1 \%$ adalah dibuat dengan memasukan $500 \mu \mathrm{L}$ TFA ke dalam labu ukur $500 \mathrm{~mL}$ dan diencerkan dengan akuabides hingga tanda batas.

Larutan dapar fosfat dibuat dengan cara menimbang $3,7250 \mathrm{~g}$ ammonium fosfat, dimasukkan ke dalam labu ukur $500 \mathrm{~mL}$, diencerkan dengan akuabides hingga tanda batas, ditambahkan asam fosfat sampai $\mathrm{pH}$ tertentu diukur menggunakan pHmeter, disaring menggunakan multipore dengan pori $0,45 \mu \mathrm{m}$ dengan bantuan vakum, diudarakan dengan ultrasonic bath selama 15-20 menit.

Optimasi kondisi KCKT serta uji kesesuaian sistem, terdiri atas penentuan panjang gelombang serapan maksimum glibenklamid, penentuan ekstingsi molar (E) dari glibenklamid, optimasi dan uji kesesuaian sistem KCKT, dan optimasi kondisi ekstraksi dengan SPE

Larutan baku glibenklamid $100 \mu \mathrm{L}$ dipipet dan dimasukkan ke dalam labu ukur $10 \mathrm{~mL}$, diencerkan dengan fase gerak sehingga diperoleh konsentrasi $5 \mu \mathrm{g} / \mathrm{mL}$.

Penentuan nilai ekstingsi molar $(\varepsilon)$ glibenklamid dilakukan dengan memipet sejumlah tertentu larutan glibenklamid dari larutan baku glibenklamid $(500 \mu \mathrm{g}$ dalam $1 \mathrm{~mL}$ metanol), dimasukkan ke dalam labu ukur $10 \mathrm{~mL}$, diencerkan dengan fase gerak sampai tanda batas sehingga diperoleh konsentrasi akhir 5, 10, $15 \mu \mathrm{g} / \mathrm{mL}$. Ketiga larutan dianalisis dengan spektrofotometer dan dibaca serapannya pada panjang gelombang maksimum glibenklamid, dan ditentukan nilai ekstingsi molarnya dengan persamaan.

Optimasi dan uji kesesuaian sistem KCKT dilakukan dengan cara larutan baku glibenklamid $(500 \mu \mathrm{g} / \mathrm{mL})$ diencerkan menggunakan fase gerak sampai diperoleh konsentrasi $2 \mu \mathrm{g} / \mathrm{mL}$, kemudian disuntikan ke dalam KCKT sebanyak $20 \mu \mathrm{L}$ dengan perbandingan fase gerak asetonitril:dapar fosfat $(40: 60), \quad(45: 55), \quad(50: 50), \quad(55: 45)$,
(60:40), dan perbandinganasetonitril:TFA (40:60), (45:55), (50:50), (55:45), (60:40). Kecepatan alir yang digunakan yaitu $1 \mathrm{~mL} /$ menit dan dideteksi pada panjang gelombang sesuai dengan hasil dari pengukuran, lalu catat waktu retensi, resolusi, dan tailing factor agar dapat menentukan fase gerak yang digunakan selanjutnya.

Optimasi kondisi ekstraksi dengan SPE dilakukan dengan cara cartridge SPE ditempatkan pada wadah. Pengondisian cartridge SPE dilakukan dengan menambahkan $1 \mathrm{~mL}$ metanol dan $1 \mathrm{~mL}$ akuabides. Sebanyak $1 \mathrm{~mL}$ sampel plasma darah manusia yang telah di-spike dengan glibenklamid, metformin, dan gliklazid dimasukkan ke cartridge SPE. Pencucian dilakukan dengan menambahkan $1 \mathrm{~mL}$ metanol 5\% dalam akuabides, kemudian analit dielusi dengan menambahkan $1 \mathrm{~mL}$ asetonitril:TFA (20:80) atau sebanyak $1 \mathrm{~mL}$ asetonitril. Analit kemudian ditampung dan disuntikkan langsung ke dalam KCKT.

Validasi metode analisis terdiri dari uji linieritas, presisi, akurasi, uji spesifisitas, uji batas deteksi, dan uji batas kuantifikasi.

Uji linieritas dilakukan dengan cara memvariasikan konsentrasi glibenklamid 5 ppm, 10 ppm, 20 ppm, 40 ppm, 80 ppm dan dicampurkan dengan 2 ppm larutan gliklazid dalam metanol. $100 \mu \mathrm{L}$ larutan campuran yang telah dibuat kemudian dimasukan pada $900 \mu \mathrm{L}$ plasma. Plasma yang sudah di-spike diekstraksi menggunakan SPE dan disuntikkan ke dalam kolom KCKT sebanyak $20 \mu \mathrm{L}$ dengan menggunakan syringe. Dibuat kurva kalibrasi dengan konsentrasi sebagai sumbu $\mathrm{x}$ dan rasio luas area puncak sebagai sumbu y. Dari kurva kalibrasi yang dibuat dilakukan analisis penentuan korelasi (r) untuk menentukan tingkat linieritas.

Uji presisi dilakukan dengan cara memvariasikan konsentrasi glibenklamid 10 ppm, 20 ppm, 40 ppm, dicampurkan dengan 2 ppm larutan gliklazid dalam metanol. 100 $\mu \mathrm{L}$ larutan campuran yang telah dibuat kemudian dimasukan pada $900 \mu \mathrm{L}$ plasma. Plasma yang sudah di-spike diekstraksi 
menggunakan SPE dan disuntikkan ke dalam kolom KCKT sebanyak $20 \mu \mathrm{L}$ dengan menggunakan syringe. Dilakukan pengulangan prosedur sebanyak lima kali pada masing-masing konsentrasi.

Uji akurasi dilakukan dengan cara memvariasikan konsentrasi glibenklamid 10 ppm, 20 ppm, 40 ppm, dicampurkan dengan 2 ppm larutan gliklazid dalam metanol. 100 $\mu \mathrm{L}$ larutan campuran yang telah dibuat kemudian dimasukan pada $900 \mu \mathrm{L}$ plasma. Plasma yang sudah di-spike diekstraksi menggunakan SPE dan disuntikkan ke dalam kolom KCKT sebanyak $20 \mu \mathrm{L}$ dengan menggunakan syringe. Dilakukan pengulangan prosedur sebanyak lima kali pada masing-masing konsentrasi. Dihitung besar persen perolehan kembali.

Uji spesifisitas dilakukan dengan cara, larutan baku glibenklamid ( $500 \mu \mathrm{g}$ dalam 1 $\mathrm{mL}$ metanol) dipipet sebanyak $200 \mu \mathrm{L}$, dan masing-masing dimasukkan ke dalam dua labu ukur $5 \mathrm{~mL}$. Larutan baku metformin (500 $\mu \mathrm{g}$ dalam $1 \mathrm{~mL}$ akuabides) dipipet sebanyak $200 \mu \mathrm{L}$, dan dimasukkan ke dalam labu ukur yang sama. Larutan baku gliklazid $(500 \mu \mathrm{g}$ dalam $1 \mathrm{~mL}$ metanol) dipipet sebanyak $100 \mu \mathrm{L}$, dan dimasukkan ke dalam labuukur yang sama. Kemudian ditambah dengan metanol sampai tanda batas sehingga diperoleh konsentrasi glibenklamid 20 ppm. Larutan campuran yang telah dibuat kemudian dimasukkan pada $900 \mu \mathrm{L}$ plasma. Plasma yang sudah di-spike diekstraksi menggunakan SPE dan disuntikkan ke dalam kolom KCKT sebanyak $20 \mu \mathrm{L}$ dengan menggunakan syringe. Dihitung nilai resolusi dan waktu retensi masing masing zat.
Batas deteksi dan batas kuantitasi dihitung secara statistik melalui garis regresi linier dari kurva kalibrasi.

Pengolahan data dan perhitungan dilakukan pada data hasil validasi metode pengukuran glibenklamid.

\section{Hasil}

Pembuatan larutan baku glibenklamid dan gliklazid adalah dengan melarutkannya di dalam metanol. Larutan baku metformin dibuat dengan melarutkannya di dalam akuabides. Fase gerak yang dioptimasi yaitu asetonitril:buffer fosfat $\mathrm{pH}$ asam dan asetonitril:TFA $0,1 \%$.

Sebelum melakukan optimasi metode menggunakan KCKT, dilakukan penentuan panjang gelombang maksimum terlebih dahulu menggunakan spektrofotometer UV-Visibel dan penentuan nilai ekstingsi molar. Pada penentuan panjang gelombang maksimum dari glibenklamid diperoleh panjang gelombang maksimum ( $\lambda$ maks) pada $227 \mathrm{~nm}$. Hasil perhitungan ekstingsi molar dapat dilihat pada Tabel 1.

Hasil dari validasi metode analisis menunjukkan linieritas metode pengujian yang dapat dilihat pada Gambar 1 dan Gambar 2. Hasil uji presisi, akurasi, dan uji spesifisitas dapat dilihat pada Tabel 2, 3, dan 4.

Hasil uji linieritas menggunakan SPE C-18, metode ini menghasilkan persamaan garis kurva kalibrasi $\mathrm{y}=0,938 \mathrm{x}+0,0831$ dengan nilai koefisien korelasi (r) 0,9984. Hasil uji linieritas menggunakan SPE MIP monomer akrilamid hasil sintesis, metode ini menghasilkan persamaan garis kurva

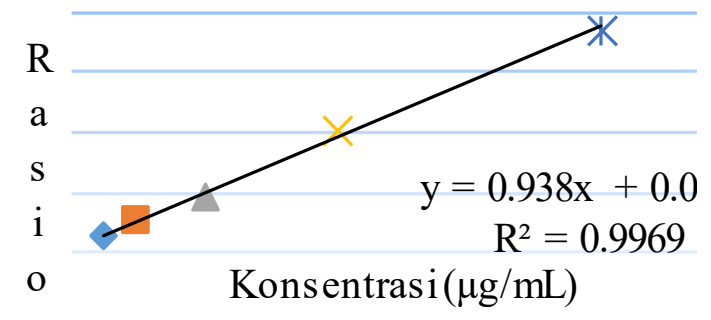

Gambar 1 Kurva Kalibrasi Metode Analisis SPE C-18 


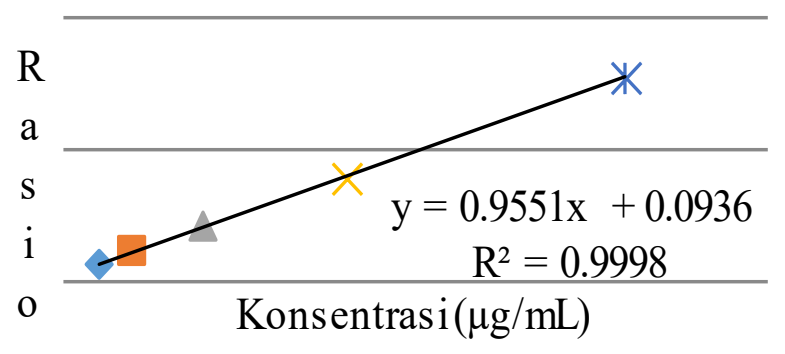

Gambar 2 Kurva Kalibrasi Metode Analisis SPE-MIP monomer akrilamid

kalibrasi $\mathrm{y}=0,9551 \mathrm{x}+0,0936$ dengan nilai koefisien korelasi (r) 0,9998.

Dari hasil optimasi kondisi ekstraksi menunjukkan bahwa kondisi optimal pada ekstraksi dengan SPE adalah menggunakan $1 \mathrm{~mL}$ metanol dan $1 \mathrm{~mL}$ akuabides sebagai conditioning agent, $1 \mathrm{~mL}$ metanol 5\% dalam akuabides sebagai washing agent, dan $1 \mathrm{~mL}$ asetonitril sebagai eluting agent.

Metode analisis menggunakan SPE C-18 memiliki batas deteksi 0,589583 $\mu \mathrm{g} /$ $\mathrm{mL}$ dan batas kuantitasi $1,965276 \mu \mathrm{g} / \mathrm{mL}$ yang artinya untuk melakukan suatu analisis dengan metode ini sampel harus memiliki kadar diatas nilai LLOQ yaitu 0,982638 $\mu \mathrm{g} / \mathrm{mL}$. Metode analisis menggunakan SPE-MIP monomer akrilamid memiliki batas deteksi $0,132066 \mu \mathrm{g} / \mathrm{mL}$ dan batas kuantitasi $0,44022 \mu \mathrm{g} / \mathrm{mL}$ yang berarti untuk melakukan suatu analisis dengan metode ini sampel harus memiliki kadar diatas nilai LLOQ yaitu $0,22011 \mathrm{~g} / \mathrm{mL}$.

Analisis data hasil validasi metode glibenklamid yang dipreparasi dengan SPE-MIP monomer akrilamid kemudian dibandingkan dengan SPE C-18, keduanya memiliki kekurangan dan kelebihannya masing-masing sehingga sangat sulit apabila

Tabel 1 Data Penentuan Ekstingsi Molar

\begin{tabular}{cc}
\hline Konsentrasi & Ekstingsi molar \\
\hline 5 & 16891,93333 \\
10 & 13698,76667 \\
15 & 13420,55556 \\
\hline
\end{tabular}

harus ditentukan SPE mana yang lebih baik. Akan tetapi secara statistik dengan analisis varian rangking dua arah

Fredman, validasi antara kedua metode memberikan perbedaan yang nyata di mana validasi analisis glibenklamid yang terlebih dahulu dipreparasi menggunakan SPE-MIP monomer akrilamid lebih baik daripada preparasi menggunakan SPE C-18.

\section{Pembahasan}

Pembuatan larutan baku glibenklamid dan gliklazid dengan menggunakan metanol sebagai pelarut karena kelarutan keduanya adalah dalam metanol, ${ }^{6}$ dan cukup baik, sehingga digunakan karena cocok untuk KCKT.

Larutan baku metformin dibuat dengan cara melarutkannya dalam akuabides. Pemilihan akuabides sebagai pelarut karena kelarutan metformin yang sangat baik dalam air. ${ }^{7,8}$

Fase gerak yang dioptimasi adalah asetonitril:buffer fosfat $\mathrm{pH}$ asam serta asetonitril:TFA (Trifluoroacetic acid) $0,1 \%$. Pemilihan kedua jenis fase gerak ini berdasarkan pada kepolaran glibenklamid

Tabel 2 Data Uji presisi

\begin{tabular}{ccc}
\hline $\begin{array}{c}\text { Konsentrasi } \\
(\mu \mathrm{g} / \mathrm{mL})\end{array}$ & $\begin{array}{c}\text { \%CV SPE } \\
\mathrm{C}-18\end{array}$ & $\begin{array}{c}\text { \%CV SPE- } \\
\text { MIP monomer } \\
\text { akrilamid }\end{array}$ \\
\hline 1 & 16,90148 & 7,730881028 \\
2 & 10,91655 & 6,933975413 \\
4 & 4,909356 & 1,07651223 \\
\hline
\end{tabular}


Tabel 3 Data Uji Akurasi

\begin{tabular}{ccc}
\hline \multirow{2}{*}{ Konsentrasi } & \multicolumn{2}{c}{ \% Recovery } \\
\cline { 2 - 3 } & SPE C-18 & $\begin{array}{c}\text { SPE-MIP } \\
\text { monomer akrilamid }\end{array}$ \\
\hline 1 & 93,16814 & 97,73067124 \\
2 & 96,89175 & 109,7588834 \\
4 & 103,0133 & 108,629593 \\
\hline
\end{tabular}

dan gliklazid sebagai analit dan internal standar dan juga nilai pKa keduanya. Glibenklamid merupakan senyawa yang mempunyai sifat asam lemah dengan nilai pKa 5,3. ${ }^{9}$ Gliklazid adalah senyawa yang mempunyai sifat asam lemah dengan nilai pKa 5,9. ${ }^{10}$ Karena keduanya merupakan senyawa asam lemah, fase gerak harus dibuat dalam kondisi asam untuk dapat menghindari terjadinya ionisasi pada kedua senyawa tersebut.

Sebelum melakukan optimasi metode menggunakan KCKT, dilakukan penentuan panjang gelombang maksimum terlebih dahulu menggunakan spektrofotometer UV-Visibel. Pada penentuan panjang gelombang maksimum dari glibenklamid diperoleh panjang gelombang maksimum ( $\lambda$ maks) pada $227 \mathrm{~nm}$. Transisi elektronik yang mungkin terjadi pada suatu senyawa adalah transisi $\sigma \rightarrow \sigma^{*}, \mathrm{n} \rightarrow \sigma^{*}, \mathrm{n} \rightarrow \pi^{*}$, dan $\pi \rightarrow \pi^{*} .11$

Pada transisi $\sigma \rightarrow \sigma^{*}$, energi yang diperlukan besarnya sesuai dengan energi sinar yang frekuensinya terletak diantara UV vakum (kurang dari 180nm). Jenis transisi ini kurang bermanfaat untuk analisis dengan spektrofotometri UVVis. Transisi $n \rightarrow \sigma^{*}$ terjadi pada senyawa organik jenuh yang mengandung atomatom yang memiliki elektron bukan ikatan (elektron $\mathrm{n}$ ). Sinar yang diserap memiliki panjang gelombang antara $150-250 \mathrm{~nm}$. Transisi $n \rightarrow \pi^{*}$ dan $\pi \rightarrow \pi^{*}$ merupakan jenis transisi yang paling cocok untuk analisis obat dikarenakan sesuai dengan panjang gelombang antara $200-700 \mathrm{~nm}$, dan panjang gelombang dapat diterapkan pada spektrofotometer. ${ }^{11}$
Berdasarkan sumber literatur, panjang gelombang serapan maksimum ( $\lambda$ maks) glibenklamid dalam metanol adalah pada $229,5 \mathrm{~nm} .{ }^{12} \lambda$ maks glibenklamid diperoleh pada 227 nm. Panjang gelombang maksimum dari glibenklamid yang didapat seperti pada penelitian Kumar et.al tahun 2015 yaitu $227 \mathrm{~nm} .{ }^{13}$

Setelah diperoleh panjang gelombang maksimum, tahap selanjutnya adalah menentukan nilai ekstingsi molar untuk memastikan bahwa panjang gelombang yang dipilih dapat dipakai untuk analisis. ${ }^{11}$ Hasil perhitungan ekstingsi molar dapat dilihat pada Tabel 1.

Dari Tabel 1 diketahui nilai ekstingsi molar lebih dari 10.000, hal ini sesuai dengan ketentuan bahwa ekstingsi molar untuk analisis adalah lebih dari 10.000. ${ }^{14}$ Data ini menunjukkan bahwa glibenklamid memberikan sensitifitas yang tinggi dan mudah dideteksi dan ditentukan kadarnya.

Hasil optimasi kondisi ekstraksi menunjukkan bahwa kondisi optimal pada ekstraksi dengan SPE adalah menggunakan $1 \mathrm{~mL}$ metanol dan $1 \mathrm{~mL}$ akuabides sebagai conditioning agent, $1 \mathrm{~mL}$ metanol 5\% dalam akuabides sebagai washing agent, dan $1 \mathrm{~mL}$ asetonitril sebagai eluting agent.

Validasi metode analisis yang dilakukan meliputi uji linieritas, uji presisi, uji akurasi, uji spesifisitas, uji batas deteksi, dan uji batas kuantifikasi.

Uji linieritas dilakukan agar dapat mengetahui kemampuan metode analisis memberikan respon secara langsung atau dengan bantuan transformasi matematik yang baik dan juga proporsional terhadap konsentrasi analit dalam sampel. Data hasil 
Tabel 4 Data Uji Spesifisitas

\begin{tabular}{cc}
\hline & Resolusi \\
SPE C-18 & SPE-MIP monomer akrilamid \\
\hline 2,352941 & 3,364341 \\
\hline
\end{tabular}

uji linieritas dapat dilihat pada Gambar 1 dan Gambar 2.

Dari hasil uji linieritas SPE C-18, menghasilkan persamaan garis kurva kalibrasi $\mathrm{y}=0,938 \mathrm{x}+0,0831$ dengan nilai koefisien korelasi (r) 0,9984. Dari hasil uji linieritas SPE-MIP monomer akrilamid hasil sintesis menghasilkan persamaan garis kurva kalibrasi $\mathrm{y}=0,9551 \mathrm{x}+0,0936$ dengan nilai koefisien korelasi (r) 0,9998. Semakin mendekati 1 nilai $r$ suatu metode, semakin baik metode tersebut. ${ }^{15}$

Pengujian presisi dari metode analisis adalah untuk menentukan ukuran yang menunjukkan derajat kesesuaian antara hasil pengujian individual, diukur melalui penyebaran hasil individual dari rata-rata jika prosedur diterapkan secara berulang pada sampel-sampel yang diambil dari campuran yang homogen. Dari hasil uji presisi, presisi dari kedua metode yang digunakan dapat dikatakan presisi karena nilai koefisien variasi (KV) pada ketiga konsentrasi memenuhi syarat yaitu nilai $\mathrm{KV}$ $<15 \%$ untuk konsentrasi tengah dan $<20 \%$ untuk LLOQ. ${ }^{15}$

Pengujian akurasi dari metode analisis adalah untuk menentukan ukuran yang menunjukkan derajat kedekatan hasil analisis dengan kadar analit yang sebenarnya. Suatu metode analisis sampel biologis dinyatakan akurat bila memiliki nilai \% recovery yaitu $85-115 \%$ dan $80-$ $120 \%$ untuk LLOQ. ${ }^{15}$ Nilai akurasi dari uji akurasi kedua metode ada pada rentang validnya suatu metode. Data uji akurasi dapat dilihat pada Tabel 3.

Uji spesifisitas dilakukan untuk dapat menentukan kemampuan metode dalam mengukur zat tertentu saja secara cermat dan seksama dengan adanya komponen lain yang mungkin ada dalam matriks sampel.
Dari hasil uji spesifisitas, kedua metode ini dinyatakan valid. Selektivitas dinyatakan dengan nilai resolusi atau daya pisah (Rs) dan nilainya lebih dari $1,5 .{ }^{16}$ Data uji dapat dilihat pada Tabel 4.

Uji batas deteksi dan batas kuantitasi dilakukan untuk menetukan jumlah terkecil analit dalam sampel yang dapat dideteksi dan dikuantitasi yang masi memberikan respon yang signifikan dan memenuhi kriteria cermat dan seksama. Metode analisis menggunakan SPE C-18memiliki batas deteksi $0,589583 \mu \mathrm{g} / \mathrm{mL}$ dan batas kuantitasi $1,965276 \mu \mathrm{g} / \mathrm{mL}$ yang berarti untuk melakukan suatu analisis dengan metode ini sampel harus memiliki kadar diatas nilai LLOQ yaitu $0,982638 \mu \mathrm{g} / \mathrm{mL}$. Metode analisis menggunakan SPE-MIP monomer akrilamid memiliki batas deteksi $0,132066 \mu \mathrm{g} / \mathrm{mL}$ dan batas kuantitasi $0,44022 \mu \mathrm{g} / \mathrm{mL}$ yang berarti untuk melakukan suatu analisis dengan metode ini sampel harus memiliki kadar diatas nilai LLOQ yaitu $0,22011 \mathrm{~g} / \mathrm{mL}$.

Analisis data hasil validasi metode analisis glibenklamid yang dipreparasi dengan SPE-MIP monomer akrilamid yang dibandingkan dengan SPE C-18, apabila dibandingkan antara kedua metode tersebut, keduanya memiliki kekurangan dan kelebihannya masing-masing sehingga sangat sulit apabila harus ditentukan SPE mana yang lebih baik. Akan tetapi, secara statistik dengan analisis varian rangking dua arah Fredman, validasi antara kedua metode memberikan perbedaan yang nyata dimana validasi analisis glibenklamid dengan preparasi menggunakan SPE-MIP monomer akrilamid lebih baik daripada preparasi menggunakan SPE C-18.

Pretreatment menggunakan SPE C-18 termasuk SPE konvensional yang memiliki 
kekurangan dari selektivitas absorbsinya,5 sedangkan MIP adalah jenis polimer dengan ikatan yang kuat yang berdasarkan atas pengenalan molekul yang direkayasa untuk mengikat satu senyawa target atau senyawa-senyawa yang strukturnya serupa dengan selektifitas yang tinggi. Selektivitas diperlihatkan pada sintesis MIP dimana molekul template dirancang untuk meniru analit, mengarahkan pembentukan rongga tertentu atau jejak yang secara sterik dan kimia berhubungan dengan analit target. Hal-hal tersebut merupakan faktor yang menyebabkan pretreatment menggunakan SPE-MIP monomer akrilamid lebih baik untuk analisis glibenklamid. Selain itu, nilai LOD dan LOQ hasil validasi metode dengan menggunakan SPE-MIP monomer akrilamid lebih rendah karena selektivitas ekstraksi meningkat secara signifikan, latar belakang lebih rendah memungkinkan analisis untuk mencapai batas deteksi yang lebih rendah. ${ }^{17}$

\section{Simpulan}

Berdasarkan pada penelitian yang telah dilakukan dapat disimpulkan bahwa kondisi optimum pemisahan glibenklamid menggunakan SPE-MIP monomer akrilamid adalah dengan menggunakan 1 $\mathrm{mL}$ metanaol dan $1 \mathrm{~mL}$ akuabides sebagai conditioning agent, $1 \mathrm{~mL}$ metanol 5\% dalam akuabides sebagai washing agent, dan asetonitril sebagai eluing agent. Analisis glibenklamid menggunakan teknik preparasi SPE-MIP monomer akrilamid memenuhi syarat validasi. SPE-MIP monomer akrilamid memberikan hasil yang lebih baik dan berbeda nyata dalam memperoleh kondisi optimum ekstraksi dibandingkan dengan SPE-C18.

\section{Daftar Pustaka}

1. Nugroho AE. Hewan percobaan diabetes mellitus: patologi dan mekanisme aksi diabetogenik. Biodiversita. 2008;7(4):378-382.
2. Yulianti E. Mikroalbuminuria pada penderita diabetes mellitus tipe 2 hipertensif. Jurnal Penelitian Saintek.2009;14(1):77-96.

3. Internatioanal Diabetes Federation. The global burden. [Diunduh tanggal 30 April 2016] Tersedia dari:http://www. idf.org/diabetesatlas/5e/the-globalburden

4. RiskayantiI. Profil Peresepan Obat Antidiabetika Oral di Beberapa Apotek di Surabaya. [Diunduh tanggal 30 April 2016] Tersedia dari:http://adln.lib.unair. ac.id/files/disk1/404/gdlhub-gdl-s12011-riskayanti-20151-ff.1131-k.pdf

5. Fontanals N, Marce RM, Borrull F. Overview of the novel sorbents available in solid-phase extraction to improve the capacity and selectivity of analytical determinations. Institut d'Estudis Catalans, Barcelon. 2010;6 (2):199-213.

6. Lakhsmi, KS, Tirumala Rajesh. Separation and quantification of eight antidiabetic drugs on a high performance liquid chromatography: its application to human plasma assay. International Scholarly Research Network. ISRN Pharmaceutics. 2011; 2011(3):7.

7. Ankit A, Govind RS, Raju S, Mithilesh, Dev JA. Gastroretentive system of metformin: an approach to enhance its oral bioavailability. International Journal of Research in Pharmacy and Science (IJRPS). 2013; 3(2):7-59.

8. Gabr QR, Padwal RS, Brocks DR. Determination of metformin in human plasma and urine by high performance liquid chromatography using small sample volume and conventional cctadecyl silane column. J Pharm Pharmaceut Sci. 2010;13(4):486-494.

9. GianotoEADS, ArantesRP, Filho, MJL, Filho ACSC, Nery MMF. Dissolution test forglibenclamide tablets. Quím Nova. 2007;30(5).1218-1221

10. Ahad HA, Kumar CS, Budideti K KR, Battula SP, Ayyavala CS. Formulation and evaluation of ficus glomerata 
mucilage sustained release matrix tablets of gliclazide. Pak. J. Pharm. Sci. 2011; 24(3):399 - 404.

11. Gandjar IG, Rohman A. Kimia farmasi analisis. Yogyakarta: Pustaka Pelajar. 2007

12. Patil SS, Bonde CG. Development and validation of analytical method for simultaneous estimation of glibenclamide and metformin $\mathrm{HCl}$ in bulk and tablets using UV - visible spectroscopy. International Journal of ChemTech Research. 2009; 1(4):905 909.

13. Kumar NA, Vargehese L, Ramesh, Ansari LHT, Kumar KS. Enhancement of dissolution ratenof glibenclamide using liquisolid technique. International Journal of Research in Pharmaceutical and Nano Sciences.2015; 4(4):206 216.

14. Colclough N, Hunter A, Kenny PW,
Kittlety RS, Lobedan L, Tam KY, Timms MA. High throughput solubility determination with application to selection of compounds for fragment screening. Bioorganic \& Medicinal Chemistry. 2008;16(13):6611-6616.

15. Naha A, Rai I, and Kamath V. Development and validation of bioanalytical method for estimation of glibenclamide. Universal Journal of Pharmacy. 2014;3(5):42-45.

16. Webster GK. Supercritical fluid chromatography: advances and applications in pharmaceutical analysis. The United State: Pan Standford Publishing; 2014. 241.

17. Shimelis O, Trinh A, Brandes $H$. The selective extraction of chloramphenicol using Molecular Imprinted Polymer (MIP) SPE. The Reporter. 2007;25(1):9 $-11$. 